\title{
MARTA GROMULSKA
}

\section{Zakład Epidemiologii}

Narodowy Instytut Zdrowia Publicznego-PZH

Chocimska 24, 00-791 Warszawa

E-mail:mgromulska@pzh.gov.pl

\section{RUDOLF WEIGL (2.09.1883-11.08.1957) - POLSKI UCZONY Z WYBORU}

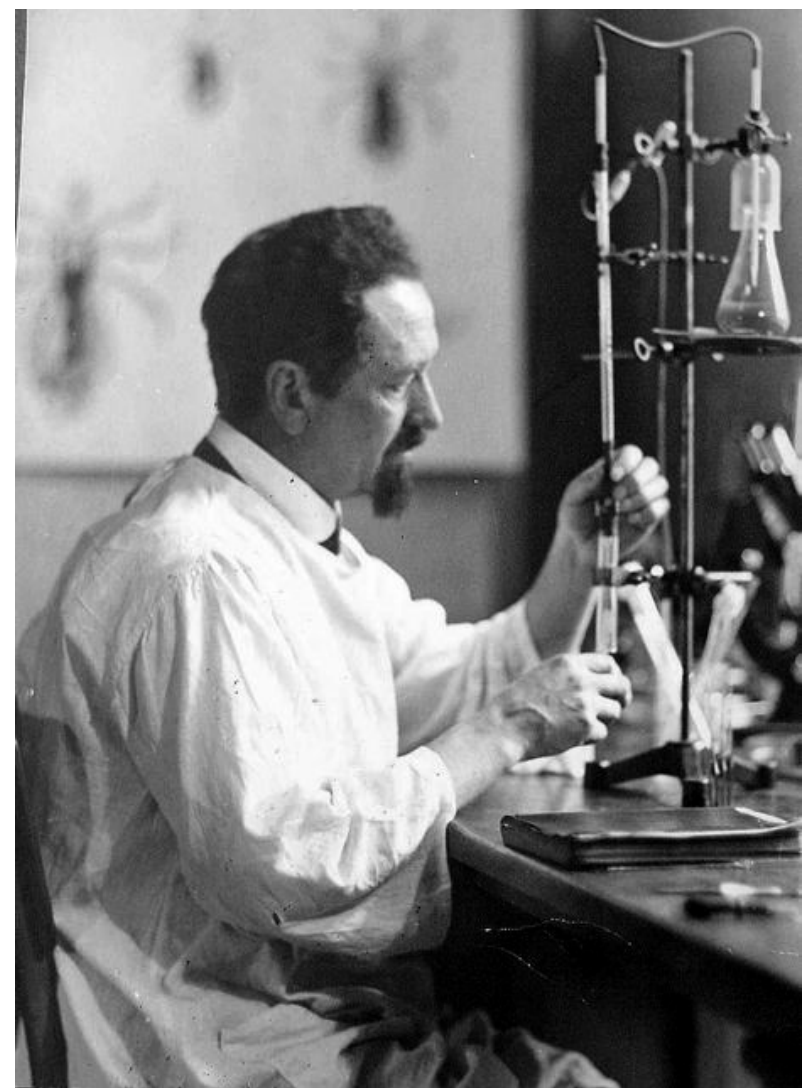

Profesor Rudolf Weigl

\section{Rudolf Weigl (1883-1957)}

Profesor, wybitny biolog $z$ Uniwersytetu Jana Kazimierza we Lwowie. Prowadził badania nad riketsjami, zarazkami tyfusu plamistego. Opracował metodę hodowli zarazka w jelicie wszy i technologię produkcji skutecznej szczepionki przeciwko tej groźnej chorobie zakaźnej. Szczepionka była produkowana w zakładzie przy Katedrze Biologii UJK i stosowana od poczatku lat 30. XX w.
Ocaliła życie tysiącom ludzi w czasie epidemii i podczas II wojny światowej.

\section{Rudolf Weigl (1883-1957)}

Professor, prominent biologist at Jan Kazimierz University in Lwow. He conducted the research on rickettsiae - microbe of epidemic typhus, and elaborated a method of Rickettsia provazeki culture in the louse gut and vaccine technology production against of this dangerous infectious disease. The vaccine was produced by Weigl Institute in Biology Department of Jan Kazimierz University. The vaccine put into practice since 30. years XX century and rescue life of the thousands of peoples in epidemic time and during World War II.

Rudolf Weigl urodził się w Przerowie na Morawach, w rodzinie austriackiej, ale po śmierci ojca Jego Matka wyszła za mąż za Polaka, Józefa Trojnara, profesora gimnazjalnego. Rodzina przeniosła się do Wiednia, a potem do Małopolski i Rudolf uczył się w polskich szkołach. W Stryju uzyskał maturę, a studia rozpoczał w 1903 r. na Wydziale Przyrodniczym Uniwersytetu Jana Kazimierza we Lwowie. W 1907 r. uzyskał stopień doktora filozofii, a w 1913 r. po habilitacji stopień docenta zoologii, anatomii porównawczej i histologii. Jako biologa interesowały Go struktury siateczkowe komórek nerwowych kręgowców i historia ich badań, tzw. aparat Golgiego-Kopscha, oraz mitochondria. Weigl starał się poznać biologię zarazka tyfusu plamistego, odkrytego w 1916 r. przez Brazylijczyka Rocha Limę.

Po wybuchu I wojny światowej został powołany do armii austro-węgierskiej i pracował w laboratoriach bakteriologicznych nad 
durem plamistym w obozach uchodźców i jeńców wojennych na terenie Czech i Moraw. Tyfus plamisty (osutkowy) powodował masową śmiertelność ludności cywilnej i wojska, a epidemie nasilały sie podczas wojen. Wielu naukowców pracowało nad wynalezieniem skutecznej szczepionki przeciwko tej chorobie.

Jeszcze podczas I wojny światowej Rudolf Weigl, jako asystent Filipa Eisenberga w laboratorium bakteriologicznym w Przemyślu, wpadł na pomysł hodowli riketsji (zarazka tyfusu plamistego, odkrytego przez Amerykanina Rickettsa i Czecha Prowazeka) przez wstrzykiwanie ich do jelit wszy, przez co można było uzyskiwać odpowiednio duża masę bakterii do produkcji szczepionki przeciw durowi plamistemu. Bakterii nie można było hodować w warunkach laboratoryjnych, bo nie rozwijały się na sztucznych pożywkach, lecz jedynie w żywych komórkach. Próby opracowania szczepionki $\mathrm{z}$ riketsji hodowanych na myszach laboratoryjnych i w zarodkach jaja kurzego nie powiodły się.

Prowadząc dalsze badania w Katedrze Biologii na Wydziale Lekarskim UJK, która jako profesor kierował od 1920 r., Rudolf Weigl opracowal metodę hodowli riketsji w jelicie wszy, traktujac wesz odzieżowa jako pożywkę biologiczna dla rozmnażania bakterii. Najpierw hodowano wszy zdrowe, potem zakażano je zarazkami tyfusu wstrzykujac je do jelit wszy, gdzie się rozmnażały, a następnie preparowano te jelita, aby uzyskać szczepionkę fenolizowana. Ponadto, w Katedrze były działy naukowo-badawczy i bakteriologii ogólnej, w których powstało 80 prac doświadczalnych, m.in.: WEIGL R., 1927. O istocie $i$ postaci zarazka duru osutkowego. Med. Dośw. Społ. 7, 1-2, 127-144; WeIGL R., 1931. Sposoby czynnego uodporniania przeciw durowi osutkowemu. Rozprawy Wydz. Lek. PAU 1, 1.

Rudolf Weigl wykrył nowy gatunek riketsji Rocha Limy. Badania opublikował w Przegladzie Epidemiologicznym, który był od poczatku czasopismem PZH (1921, 1 , 1 , 365-375), a po wznowieniu wydawania Przegladu w 1948 r. (Metody walki $z$ durem osutkowym. Przegl. Epidemiol. 2, 1-2, 3-19).

Współpracowali $z$ Nim znani bakteriolodzy: Charles Nicolle, który otrzymal nagrode Nobla w 1928 r. za odkrycie, że przenosicielem duru plamistego jest wesz odzieżowa, Stanisław Weil, kierownik Instytutu Farmaceutycznego, który mieścił się w PZH, Helena Sparrow, która prowadziła badania nad szczepionkami przeciw tyfusowi w PZH w latach 30., Ludwik Anigstein, parazytolog w $\mathrm{PZH}$, znawca epidemiologii tyfusu, badacz riketsji jako pasożytów.
W 1934 r. szczepionka Weigla zaczęła być stosowana $\mathrm{w}$ Polsce wśród personelu sanitarnego i osób narażonych na zakażenie durem plamistym. Pierwsza akcje szczepień ochronnych przeprowadził jej twórca we wschodniej Małopolsce wśród Hucułów, gdzie częste były epidemie tyfusu. Przed akcjami szczepień prowadzono $\mathrm{w}$ terenie rozpoznanie epidemiologiczne.

Szczepionka Weigla stała sie znana na całym świecie, a Jego metoda dała podstawy uruchamiania zakładów produkujących szczepionkę. W latach 30. szczepionka ocaliła życie misjonarzom wysyłanym do krajów azjatyckich, za co papież Pius XI nadał prof. Weiglowi Order Św. Grzegorza. Za szczepienia ochronne w kolonii belgijskiej król Belgów odznaczył Go orderem Leopolda.

W 1937 r. na zaproszenie Ligi narodów Weigl wygłosił cykl referatów w Genewie na temat tyfusu plamistego. Nawiązał współprace ze szwedzkim towarzystwem lekarskim w Sztokholmie.

Szczepionka Weigla była stosowana w koloniach włoskich i francuskich w Afryce, w Australii i w Chinach, i wszedzie tam, gdzie dur plamisty szerzył się epidemicznie. Rudolf Weigl był zaproszony do Abisynii, gdzie badal ogniska tyfusu plamistego i pobrał próby zarazków do dalszych badań.

Polskie Ministerstwo Spraw Wojskowych zwróciło się do Weigla o zorganizowanie na wielka skalę produkcji szczepionki dla wojska polskiego i ludności cywilnej na wypadek wojny, lecz nie zdażono wykonać tego zadania przed jej wybuchem.

Po opanowaniu Lwowa we wrześniu 1939 r. sowieci zreorganizowali Wydział Lekarski Lwowskiego Uniwersytetu. Powstał Lwowski Instytut Medyczny, ale w jego skład wszedł zakład i pracownia badań nad tyfusem plamistym Weigla. W lutym $1940 \mathrm{r}$. N. Chruszczow zaproponował Rudolfowi Weiglowi wysoki tytuł akademika Wszechzwiazkowej Akademii Nauk ZSRR, ale Weigl nie skorzystał $z$ propozycji, chociaż na zaproszenie Ministerstwa Zdrowia ZSRR wygłaszał odczyty o biologii zarazka tyfusu plamistego w Moskwie, Leningradzie, Kijowie i Charkowie.

Po zajęciu Lwowa w lipcu 1941 r. Niemcy nie zlikwidowali Instytutu Weigla (dzialał pod nazwa Institut fur Fleckfieber und Virusforschung des $\mathrm{OKH}$ ) i pozostawili $\mathrm{Mu}$ wolną rękę w organizacji i doborze pracowników. Szczepionka chroniła przed tyfusem armię niemiecka, a Weiglowi proponowano stanowiska naukowe w Berlinie, w zamian za podpisanie Reichlisty. Gdy odmówił, grożono $\mathrm{Mu}$ śmiercia, przypominajac egzekucję lwowskich profesorów na Wzgórzach Wuleckich 4 lipca 1941 r. Rudolf Weigl nie wy- 
rzekł się swojej polskiej narodowości i nie przeląkł gróźb generała Katzmanna, zastępcy Himmlera.

Szczepionka przeciwko tyfusowi plamistemu była podczas okupacji niemieckiej produkowana dla Wermachtu, ale potajemnie rozsyłana i przewożona do gett lwowskiego i warszawskiego oraz do członków konspiracji. Łacznikiem między Warszawa i Lwowem był m.in. dr Edward Mikołajczyk, asystent dr Henryka Mosinga, który przywoził szczepionki do PZH, skąd były rozsyłane do kolumn sanitarnych i więzień, a także uczestniczył $\mathrm{w}$ tajnej produkcji prowadzonej w PZH przez dr Feliksa Przesmyckiego, dr Edmunda Wojciechowskiego (po wojnie twórcy pracowni Riketsji w Zakładzie Bakteriologii PZH.) i dr Tadeusza Przyborowskiego.

Dr Edward Mikołajczyk poświęcił 47 lat pracy naukowo-badawczej nad riketsjami i epidemiologia innych chorób zakaźnych w PZH pracujac, a nastepnie kierujac Pracownia Riketsji w Dziale Bakteriologii od $1967 \mathrm{r}$.

W Państwowym Zakładzie Higieny pod zarządem niemieckim utworzono, prowadzony przez Niemca Hermanna Wohlraba, zakład produkcji szczepionki przeciw durowi plamistemu dla wojska niemieckiego przed planowana inwazja na Zwiąek Radziecki. Karmicielami wszy byli Polacy.

Szczepionka przeciw tyfusowi plamistemu była produkowana również w Krakowie w Zakładach Bujwida i w prywatnym laboratorium prof. Mariana Gieszczykiewicza. Niemcy wpadli na trop i znaleźli w laboratorium profesora zakażone wszy, za co był On osadzony w więzieniu na Montelupich i tam katowany, a potem zamordowany w Oświęcimiu.

W Instytucie Weigla we Lwowie karmicielami wszy i strzykaczami (z precyzja wstrzykiwali zarazki do jelit wszy za pomoca cienkiej szklanej kapilary) byli intelektualiści, profesorowie Uniwersytetu, Żydzi zagrożeni izolowaniem w gettach i obozach koncentracyjnych, studenci. Weigl zatrudniał wielu Lwowian, którzy po zaszczepieniu przeciw tyfusowi plamistemu pracowali przy produkcji szczepionki. Współpracownicy prof. Weigla dali po wojnie świadectwo wielkiej odwagi profesora, bowiem na opublikowanych listach ocalonych przez Niego znalazło się przeszło 500 osób. Lwowianie pracujacy w Instytucie (ok. 1200 osób) dostawali Ausweisy chroniace przed aresztowaniem i łapankami. Weigl zatrudnił m.in. bakteriologa Henryka Meisla, który, jako ceniony współpracownik naukowy, był doprowadzany $Z$ lwowskiego getta do Instytutu pod eskorta żołnierza niemieckiego. Po wojnie prof. Meisel kierował Zakładem Badania Surowic i
Szczepionek w PZH, utworzonym dla Ludwika Hirszfelda jeszcze w 1920 r., i zainicjował powstanie tam Muzeum Szczepów i Pracownię Beztlenowców.

W 1942 r. Weigl wysłał do Warszawy Henryka Mosinga ze szczepionkami dla Ludwika Hirszfelda, który od 1941 r. był wysiedlony $z$ PZH do getta warszawskiego, gdzie ratował Żydów przed tyfusem.

W 1944 r. wycofujacy się Niemcy zrabowali najwartościowszy sprzęt $z$ Instytutu Weigla. W lipcu tego roku miejsce Niemców zajęli Rosjanie.

Profesor Weigl opuścił Lwów i w Krościenku nad Dunajcem założył prywatna pracownię bakteriologiczną.

W Krakowie na Uniwersytecie Jagiellońskim powierzono $\mathrm{Mu}$ kierownictwo II Katedry Mikrobiologii, nazwanej Zakładem Bakteriologii Ogólnej, a 3 lipca 1945 r. władze państwowe mianowały $\mathrm{R}$. Weigla profesorem zwyczajnym.

W Krakowie prof. Rudolf Weigl został oskarżony przez nieżyczliwych Mu ludzi o kolaborację $z$ Niemcami podczas swojej działalności we Lwowie. Oczyszczony $z$ zarzutów, chciał w Krakowie udoskonalać szczepionkę przeciw tyfusowi w utworzonym przez siebie niewielkim laboratorium i starał się pozyskać fundusze $z$ Ministerstwa Zdrowia. Laboratorium, wzorowane na lwowskim Instytucie, funkcjonowało pod formalnym nadzorem PZH i Wojewódzkiej Stacji Sanitarno-Epidemiologicznej w Krakowie, przed powstaniem Zjednoczenia Wytwórni Surowic i Szczepionek.

Ostatnim miejscem działalności Profesora Rudolfa Weigla był Uniwersytet Poznański, gdzie w latach 1948-1950 kierował Katedra Biologii Ogólnej.

Rudolf Weigl przeszedł na emeryturę w 1951 r. Zmarł w Zakopanem w 1957 r. i został pochowany na Cmentarzu Rakowickim w Krakowie.

Od 1930 r. Rudolf Weigl był członkiem PAU, a od 1933 r. Towarzystwa Naukowego Warszawskiego.

Nagrody: Oprócz wspomnianych nagród od Papieża i króla Leopolda, Rudolf Weigl został w 1937 r. laureatem nagrody naukowej Miasta Lwowa im. Benedykta Dybowskiego. Kilkakrotnie Rudolf Weigl był kandydatem do Nagrody Nobla: (1) w 1936 r. przeszkodziły względy formalne, (2) w czasie wojny w 1942 r. Niemcy odmówili poparcia jako rewanż za odmowę podpisania Volkslisty i objęcia przez Weigla katedry w Berlinie, (3) a w 1948 r. władze polskie nie zgadzając się $z$ odrzuceniem przez Szwedzka Akademię zgłoszonego do literackiej Nagrody Nobla Jarosława Iwaszkiewicza, nie przywią- 
zały należytej wagi do poparcia kandydatury Rudolfa Weigla.

Pośmiertnie odznaczono Weigla Krzyżem Komandorskim Orderu Odrodzenia Polski z Gwiazda.

Dopiero w 2003 r., 46 lat po śmierci Rudolfa Weigla, Instytut Yad Vashem uhonorował Go Medalem i Dyplomem „Sprawiedliwy wśród Narodów Świata".

W latach 1947-1950 Rudolf Weigl by1 członkiem komitetu redakcyjnego Przeglądu Epidemiologicznego.

\section{BIBLIOGRAFIA}

BILEK M., 2007. Krakowskim szlakiem profesora Rudolfa Weigla. Alma Mater UJ 96; http:// www.lwow.home.pl/weigl/bilek/krakow/html.

CIESZYŃSKI T., 2005. Wspomnienie wygłoszone na sesji naukowej $w$ Instytucie Immunologii $i$ Terapii Doświadczalnej PAN we Wrocławiu $z$ okazji odsłoniecia obelisku ku czci prof. Rudolfa Weigla $w$ dniu 8 grudnia 2005 r. Post. Hig. Med. Dośw. https://www.microbiology.pl/ wp-content/uploads / 2017 / 05/Rudolf-Weigl1883-1957-II.pdf.

PAWŁOWSKI Z., 2014. Okres poznański działalności Prof. Rudolfa Weigla (1948-1951). Hygeia Public. Health 49, 765-768.

SZYBALSKI W. Wykorzystanie wszy laboratoryjnych karmionych przez ludzi dla produkcji szczepionki Weigla przeciw tyfusowi plamistyemu. (tłumaczenie z: MARAMOROSCH K. I, MAHMOOD, F., 1999. Maintenance of Human, Animal, and Plant Pathogen Vectors. Science Publishers, Inc., Enfield, NH, USA, 161-180), http:// lwow.home.pl/tyfus.html.

TYLEWSKA-WIERZBANOWSKA S. ZIELIŃSKI Z., CHMIELEWSKI J., 2003. Rudolf Weigl - człowiek $i$ uczony. Przegl. Epidemiol. 57, 225-230.

WOJCIECHOWSKI E., 1957. Prof.dr Rudolf Weigl (ur.2.09.1883 r. - zmart 11.08.1957 r.) Wspomnienie pośmiertne. Przegl. Epidemiol. 11, 2.

ZŁOTORZYCKA J., 1998. Profesor Rudolf Weigl (1883-1957) $i$ Jego Instytut. Analecta. Studia i Materialy $z$ Dziejów Nauki 1, http://www. lwow.home.pl/analecta.html. 